\title{
FEASIBILITY ASSESSMENT FOR DRILLING AND REHABILITATION OF WATER SUPPLY BOREHOLE SCHEME AT AWARO CAMPUS, AMBO UNIVERSITY
}

\author{
Mr. Tibebu Tsegaye Zigale \\ Assistant Professor, \\ Department of Hydraulic and Water Resource \\ Engineering \\ Ambo University, Ambo, Ethiopia
}

\author{
Dr. Basavaraj Paruti \\ Professor, \\ Department of Hydraulic and Water Resource \\ Engineering \\ Ambo University, Ambo, Ethiopia
}

\begin{abstract}
Groundwater is a crucial element to water systems and supplies of small to large communities worldwide. This study is based on review of relevant previous studies, primary data collected through comprehensive field survey in the project area Ambo University Institute of Technology, secondary data gathered from various offices at regional levels, and consultations with project affected communities, Administrators, key stakeholders, NGOs and relevant experts. The cause of failure of the bore well is assessed and parts of the scheme component that need maintenance, repair and replacement in addition to water quality condition is estimated in monetary value to undertake systematic cost benefit analysis to decide whether to drill new boreholes or rehabilitate existing sites. Document analysis, interviewing, group discussion and reconnaissance survey/observational approach is used to gather data and information. The Costs and benefits of borehole drilling and rehabilitation analysis was estimated. The total cost was estimated at US\$31,282 in the borehole drilling and US\$ 10,167 in the borehole rehabilitation. The total economic benefit was estimated to be US\$140,385 for 20 years in the borehole drilling and US\$ 28,513 for 10 years in the borehole rehabilitation. The cost-benefit ratio was 4.5 for borehole drilling and 2.8 for borehole rehabilitation. The output of this analysis revealed that constructing the new borehole is better than rehabilitating that would save the institute from wastage of time and capital planned for rehabilitation in addition to sustainability and reliability function of the borehole for long period of time
\end{abstract}

Keywords-Borehole/Well, feasibility, Benefit-Cost, drilling, rehabilitation.

\section{INTRODUCTION}

Groundwater is recognized as one of the most important and dependable sources of water supply in all climatic regions across the world. Although it needs further detailed investigation, according to the current knowledge, Ethiopia has about 124.4 billion cubic meter river water, $70 \mathrm{BCM}$ lake water, and $30 \mathrm{BCM}$ groundwater resources. In many parts of the country, groundwater is an important source of domestic and industrial water use especially in rural areas and towns. However, the occurrence of groundwater is not uniform because it depends on various environmental and geological factors.

Sub-Saharan Africa has the lowest drinking water coverage of any region. In more remote areas in Cameroon, the major source works for water supply are wells and boreholes. Equally, some boreholes are constructed to improve the capacity of the public water network. Some industries also extract their potable water directly from aquifers. The same thing is exercised in Ethiopia where much of the population live in rural area. There is a great portion of people in the country without access to safe drinking water, many of whom are amongst the poorest and most vulnerable. All sources confirm that water supply coverage in Ethiopia is on a strong upward trajectory. According to official government data, water supply coverage has risen from 19 percent in 1990 (11 percent rural, 70 percent urban) to 66 percent in 2009 (62 percent rural, 89 percent urban). Consequently, increasing access to improved water supplies is a major priority today.

Drilling and rehabilitation of borehole water for water supply is a common practice all over the world, especially in developing countries like Ethiopia. It is known that more than 
Table 1: Water scheme failure rate by region and basin

\begin{tabular}{|l|c|c|c|c|c|c|c|c|}
\hline \multirow{2}{*}{ Region } & \multicolumn{2}{|c|}{ All Surveyed } & \multicolumn{2}{c|}{ Developed Springs } & \multicolumn{2}{c|}{ Hand Pumps } & \multicolumn{2}{c|}{ Boreholes } \\
\cline { 2 - 9 } & Total & NF(\%) & Total & NF & Total & NF & Total & NF \\
\hline Benshagul & 125 & 67 & 9 & 0 & 116 & 72 & 0 & 78 \\
\hline Gambela & 102 & 48 & 10 & 0 & 14 & 0 & 56 & 34 \\
\hline Somali & 56 & 34 & 0 & & 0 & & 467 & 38 \\
\hline SNNPRS & 830 & 32 & 155 & 10 & 208 & 37 & 467 & 42 \\
\hline Oromia & 2571 & 24 & 1305 & 16 & 856 & 27 & 410 & 27 \\
\hline Amhara & 634 & 22 & 359 & 27 & 248 & 17 & 27 & 0 \\
\hline Tigray & 686 & 18 & 45 & 27 & 208 & 24 & 433 & 14 \\
\hline Total & 5004 & 26 & 1883 & 18 & 1650 & 29 & 1471 & 33 \\
\hline
\end{tabular}

\begin{tabular}{|l|l|l|l|l|l|}
\hline Data Source & Region/Basin & $\begin{array}{l}\text { Total } \\
\text { Schemes }\end{array}$ & FN & NF & $\begin{array}{l}\% \text { Failed } \\
\text { Schemes }\end{array}$ \\
\hline $\begin{array}{l}\text { Genale Dawa } \\
\text { Master Plan } \\
\text { Study,2007 }\end{array}$ & $\begin{array}{l}\text { Genale River } \\
\text { Basin }\end{array}$ & 1,159 & 433 & 294 & 40 \\
\hline $\begin{array}{l}\text { Netsanet } \\
\text { Kassa,2007 }\end{array}$ & Ziway Shalla & & & & 75 \\
\hline Desta Horecha & $\begin{array}{l}\text { Mekelle } \\
\text { outlier }\end{array}$ & 1,262 & 1,076 & 174 & 14 \\
\hline SNNPR & South Omo & 5,445 & 3,895 & 1,560 & 26 \\
\hline
\end{tabular}

Source: S. Kebede, Groundwater in Ethiopia, 2013

$85 \%$ of the people of Ethiopia live in rural area. over $90 \%$ of the population living in rural Ethiopia have no access to potable water. At different time several borehole wells have been drilled in Ethiopia by different governmental and nongovernmental bodies but nearly half of water schemes developed in Ethiopia for community water supply, irrigation or supplying urban centers fail or have at least substantially failed prior to delivering the desired objective.

In Ethiopia a number of failed groundwater schemes existed but little documented evidence is available as to the causes of water scheme failures. There are several basic causes of well problems. Water well problems could result from many causes including equipment failure, incomplete well development, borehole stability problems, incrustation build-up, biofouling, depletion of the aquifer, corrosive qualities of the water and improper well design and construction. Those causes either relate to the expertise and performance of the licensed water well contractor or characteristics of the aquifer plus by well users. As a result of this in Ethiopia many functional water well became nonfunctional. The four common symptoms associated with most water well problems are reduced well yield, sediment in the water, change in water quality and dissolved gas in the water from which reduced well yield and the change in water quality are the problems that are visually seen in the case of well under study. The cause of well problem can be the result of a combination of causes and therefore correction may be a combination of actions.

Water scheme failure is significantly undermining return on investment and sustains the situation of water supply emergency. Lack of sustainability and reliability of water supply services are key problems in rural area of Ethiopia. Among above mentioned major causes of these problems, it was observed that the borewell in the Awaro campus has reduction in discharge and poor quality of water, in which the pump operates below the specified capacity. As a result administrative intervention measures had been taken to prevent the burning of the pump. Even though yield of well is large, discharge is very less, due to leakage of water from casing connection point. But replacement of casing and related parts which is very difficult after installation. A number of 


\section{International Journal of Engineering Applied Sciences and Technology, 2021 \\ Vol. 5, Issue 12, ISSN No. 2455-2143, Pages 176-181 \\ Published Online April 2021 in IJEAST (http://www.ijeast.com)}

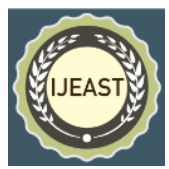

literatures state that rehabilitation is better than drilling only whenever there is simple replacement other than casing/screen.

Among professionals is the field it is believed that up to $70 \%$ of developed water wells fail to deliver water after construction in some areas (Table 1).

This study will contribute to the university that enable the institute to have groundwater as an alternative source of water for drinking in addition to supply from outside of the campus the town groundwater which directly supply to student food cafeteria. So by making this it reduces educational time wastage which became a cause for instability within the institute by students when the water supply is interrupted but if the institute would have its own source of water supply, it at least gives relief to some extent until the normal supply came into function. The Ethiopian standard of water quality for drinking water and the WHO guideline are compared to the existing borehole water. During water quality test some physical test should be performed for testing of its physical appearance such as temperature, color, odor, $\mathrm{pH}$, turbidity, TDS etc., while chemical tests should be performed for its BOD, COD, dissolved oxygen, alkalinity, hardness and other characters. For obtaining more and more quality and purity water, it should be tested for its trace metal, heavy metal contents and organic i.e. pesticide residue. It is obvious that drinking water should pass these entire tests and it should content required amount of mineral level in addition all preexisting boreholes within a project area should be inspected for the possibility of rehabilitation, without doing this it is wrong rehabilitating water well that has been closed for more than three years. The present study has been focused to conduct a detailed analysis of water supply Borehole Scheme at Awaro Campus, Ambo University to fulfill the following objectives:

1. To assess the cause failure of the water well.

2. To examine the overall status of the existing components of the borehole.

3. To undertake systematic cost benefit analysis to decide whether to drill new borehole or rehabilitate existing site.

\section{MATERIALS AND METHODS}

\section{A. Study area description}

This study was conducted at the Institute of Technology (IOT), Ambo University, Ethiopia. Ambo is located in the West Shewa zone of the Oromia region, $125 \mathrm{~km}$ west of Addis Ababa, this town has a latitude of $8^{\circ} 59^{\prime} \mathrm{N}$, longitude of $37^{\circ} 51^{\prime} \mathrm{E}$ and an elevation of 2101 meters as shown in figure 1. The institute of technology campus of the Ambo University which is dedicated to engineering departments, housing more than 7000 students. The existing borehole as shown in figure 2 was working with its full capacity up to 2015. But the borehole was functioning and supplying water to meet the requrements of institute from 2014. After it has been working with the yield of $25-26$ litre/sec at the time of construction was reduced to 14-15 litre/sec. Because of this, maintenance and borehole washing has been done, so by doing this restarted to function the institute up to the end of 2015 but without much working, because of getting reduced yield capacity of the borehole decided to stop function.

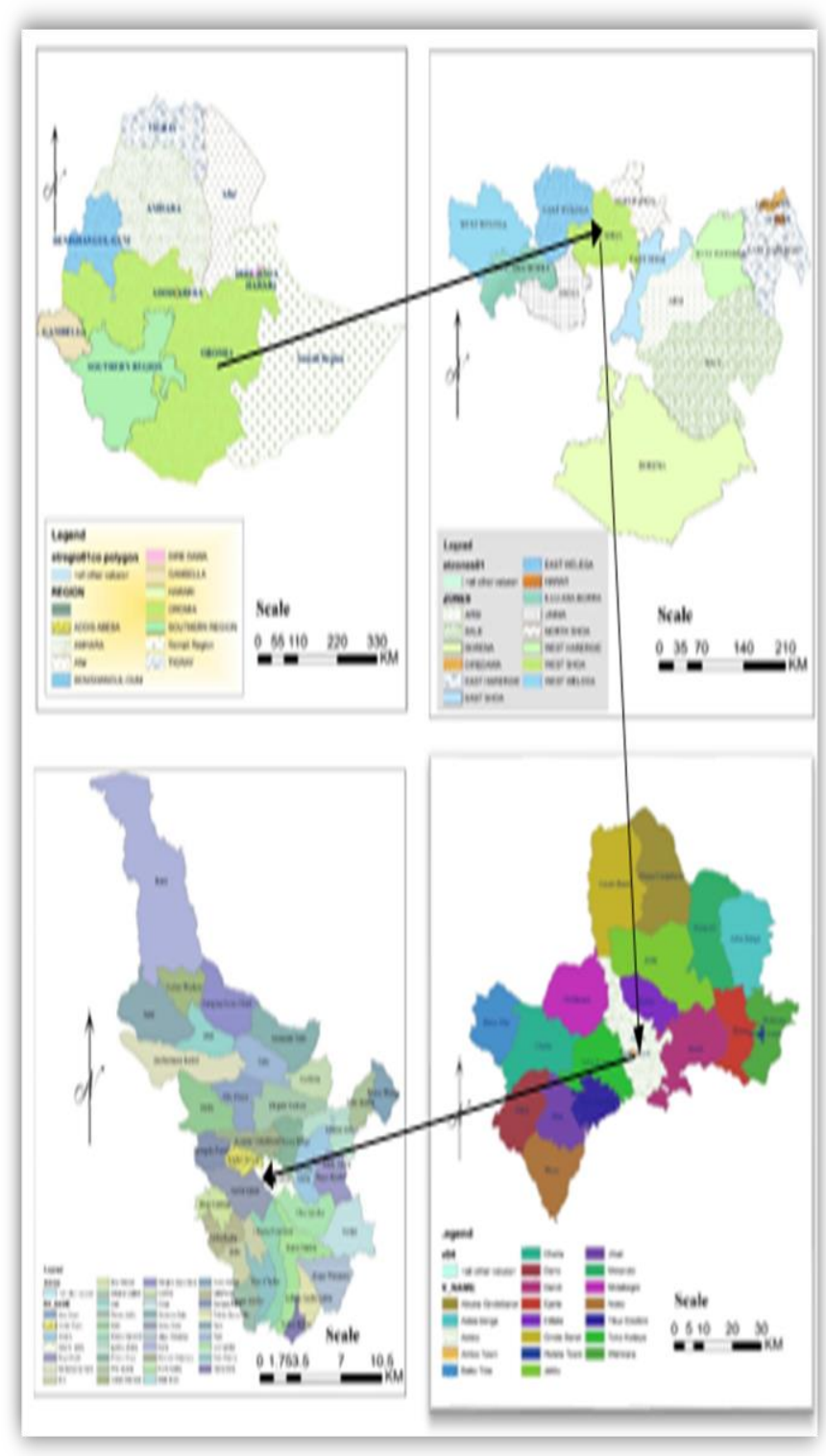

Fig. 1: Location of the study area

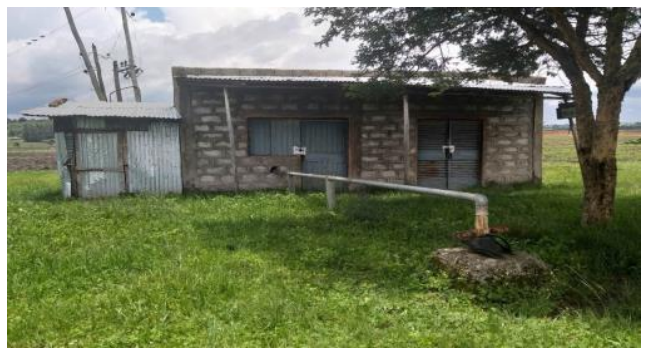


Fig. 2: Awaro Campus Water Borehole

\section{B. Methods of Assessment and Evaluation used -}

Document analysis, interviewing, focus group discussion and reconnaissance survey/observational approach was used to gather data and information. Historical financial performance, availability of financial resources, financial requirement for current market of similar size and nature, construction experience in key activities sought. The typical standard steps followed during groundwater exploration was assessed and kept, each step elaborated, study cost (professional fees, geophysics test, soil test cost, water quality parameters test cost, boring machine cost, casing material cost, stainless steel pipes with accessories cost, motor and pump cost, discharge test/geologist cost) up to making the borehole to supply water for the institute was considered. A number of literatures and documents were reviewed to identify all components and parameters with their costs. The scope of work includes the design, construction, manufacturing, commission and testing of full operational groundwater source borehole unit with regard to cost incurred to the best case was overviewed and following evaluation criterias were used Pump, casing/screen, water quality, yield reduction

$\checkmark \quad$ Length of time (closure)

$\checkmark$ Sewerage system of the institute

$\checkmark$ Dumping site (waste food discharge to the open air from student cafeteria), elevation \& slope

$\checkmark$ Agricultural practice around the borehole

$\checkmark$ Watershed/drainage characteristics around the borehole

$\checkmark$ The institute waste treatment plant (infiltration), elevation \& slope

$\checkmark \quad$ The university management intention

In the mean time few parameters are considered for calculating the benefit and cost for borehole drilling and rehabilitation as mentioned in table 2 .

Table 2. Parameters Considered for Benefits and Costs

\begin{tabular}{|l|l|}
\hline Item for both drilling and rehabilitation & \multicolumn{1}{|c|}{ Description } \\
\hline Borehole water capacity, depth & $\begin{array}{l}25-6 \text { litre/second, } \\
96 \mathrm{~m}\end{array}$ \\
\hline Approximate Number of communities at IOT & 10,000 \\
\hline Average student intake capacity/year. & $2.65 \%$ \\
\hline General Items cost for drilling & 262,000 \\
\hline Drilling cost & $4,068,327$ \\
\hline Pipe work & $17,057,816$ \\
\hline Civil Works & $3,953,713$ \\
\hline Electro-mechanical works & $5,832,208$ \\
\hline Drilling Equipment rate per meter of depth & 14,000 \\
\hline
\end{tabular}

Life span of boreholes

$20 \& 10$ years for drilling and rehabilitation respectively

Source: WHO survey data

\section{RESULTS AND DISCUSSIONS}

The Costs and benefits of borehole drilling and rehabilitation analysis was estimated based on the above criterias through group discussions, document analysis and indepth interviews. The results for the benefits and costs are presented in Table 3. The costs for operation, maintenance, surveillance, and water source protection were derived using an average of $5 \%$ of the annualized investment cost $[6,21]$. The total cost was estimated at US\$31,282 in the borehole drilling and US\$ 10,167 in the borehole rehabilitation. The total economic benefit was estimated to be US\$140,385 for 20 years in the borehole drilling and US\$28,513 for 10 years in the borehole rehabilitation. The cost-benefit ratio was 4.5 for borehole drilling and 2.8 for borehole rehabilitation, suggesting that the borehole drilling program was more cost beneficial than the borehole rehabilitation program in this empirical costbenefit analysis study. The output of the analysis revealed that constructing the new borehole is better than rehabilitating that would save the institute from wastage of time and capital planned for rehabilitation in addition to sustainability and reliability function of the borehole for long period of time.

Table 3. Economic benefits and costs of borehole drilling and rehabilitation (present value in 2020)

\begin{tabular}{|c|l|r|r|}
\hline \multicolumn{2}{|c|}{ Descriptions } & $\begin{array}{l}\text { Borehole } \\
\text { drilling }\end{array}$ & $\begin{array}{l}\text { Borehole } \\
\text { rehabilit } \\
\text { a-tion }\end{array}$ \\
\hline Benefit & $\begin{array}{l}\text { Expected economic } \\
\text { benefits from } \\
\text { productive years }\end{array}$ & $44,334.8$ & $22,167.4$ \\
\cline { 2 - 4 } & $\begin{array}{l}\text { Treatment cost } \\
\text { saved }\end{array}$ & 293.7 & 90.2 \\
\cline { 2 - 4 } & $\begin{array}{l}\text { Opportunity cost } \\
\text { during non- } \\
\text { productive years }\end{array}$ & $88,669.6$ & $32,48.5$ \\
\cline { 2 - 4 } & $\begin{array}{l}\text { Consultation cost } \\
\text { saved }\end{array}$ & $7,086.5$ & $3,007.2$ \\
\hline Cost & $\begin{array}{l}\text { Initial investment } \\
\text { cost }\end{array}$ & $27,683.5$ & $8,125.8$ \\
\cline { 2 - 4 } & $\begin{array}{l}\text { Operation and } \\
\text { Maintenance cost }\end{array}$ & $2,195.0$ & $1,088.2$ \\
\cline { 2 - 4 } & $\begin{array}{l}\text { Water quality } \\
\text { control cost }\end{array}$ & $1,403.9$ & 953.1 \\
\hline \multicolumn{2}{|c|}{ Total benefit } & $140,384.5$ & $28,513.3$ \\
\hline
\end{tabular}




\section{International Journal of Engineering Applied Sciences and Technology, 2021 \\ Vol. 5, Issue 12, ISSN No. 2455-2143, Pages 176-181 \\ Published Online April 2021 in IJEAST (http://www.ijeast.com)}

\begin{tabular}{|l|r|r|}
\hline Total cost & $31,282.4$ & $10,167.1$ \\
\hline Benefit-cost ratio & $\mathbf{4 . 5}$ & $\mathbf{2 . 8}$ \\
\hline
\end{tabular}

\section{CONCLUSION}

Efficient and economic use of natural resources plays a vital role in the development of the communities of any country. In view of exploiting natural ground water resource from the specific location of any region of the country, scientific approach is very much essential. It was revealed from this study that lack of scientific approach, before drilling the bore holes in institute of technology campus of Ambo University area has failed due to the sedimentation in the boreholes. The failure of boreholes due to the improper casings in the boreholes. Before drilling the boreholes in the specific area, it is very much essential to study the appropriate depth of casing needs to be provided based on the ground water table, geological formation and soil profile. Ultimately which can reduce the sedimentation in the bore hole and blockage of pumps. By adopting this approach, we may achieve the long durability and reduce the maintenance cost of boreholes.

Therefore, the institute of technology Ambo university should have its own source of water supply in order to assure a conducive learning teaching environment by drilling a number of new boreholes within the campus that adequately supply water to the whole community of the institute as far as the area has good potential of groundwater

\section{ACKNOWLEDGMENT}

The author wishes to acknowledge staff members for their valuable critics that have contributed much to improving this paper.

\section{REFERENCE}

[1] Groundwater for Sustainable Development, affiliated with the International Society of Groundwater for Sustainable development (www.elsevier.com/locate/gsd)

[2] Aladejana J.A. and Talabi A.O, Assessment of Groundwater Quality in Abeokuta Southwestern, Nigeria, International Journal of Engineering and Science.

[3] Fatemeh Karandish, Arjen.Y. Hoekstra, Rick J. Hogeboom, Groundwater saving and quality improvement by reducing water footprints of crops to benchmarks levels, Elsevier, Advances in Water resources.

[4] Strategic Framework for Managed Groundwater Development (February 2011, Ethiopia)
[5] Groundwater Quality in Nigerian Urban Areas: A Review. By Ocheri, M. I, L.A.Odoma \& Umar.N.D, (C)2014 Global Journals Inc. (US)

[6] S. Cha, et al. (2018). Cost-benefit analysis of water source improvements through borehole drilling or rehabilitation: an empirical study based on a cluster randomized controlled trial in the Volta Region, Ghana. Global Health Action Journal

[7] S. Kebede, 2013. Groundwater in Ethiopia, Springer Hydrogeology.

[8] Technical Review, Borehole Drilling and Rehabilitation Under Field Conditions: International Committee of the Red Cross, February 2010.

[9] J. A. Akudago et al. (2009). Borehole Drying: A Review of the Situation in the Voltaian Hydrogeological System in Ghana, J. Water Resource and Protection.

[10] Mokuolu,O.A.et al. (2017). Groundwater quality Assessment near a Nigerian dumpsite: Ethiopian Journal of Environmental Studies \& Management 10(5): 588 596.

[11] C. Defo et al. (2016). Current conditions of groundwater resources development and related problems in the Republic of Cameroon, West Africa, European Water 54: 43-68.

[12] B. Berhanu et al. (2014). Surface water and Groundwater Resources of Ethiopia: Potentials and Challenges of water Resources development. Research Gate.

[13] Carter, RC. 2006. Ten step Guide Towards Cost-effective Boreholes. Field Note RWSN/WSP

[14] Abebe G. Hiwot, 1999. Case studies on well drilling problems. Integrated development for Water Supply and Sanitation, 25th WEDC Conference, Addis Ababa, Ethiopia.

[15] K. Danert, R.C. Carter, D. Adekile, A. MacDonald, \& E. Baumann, Switzerland.Cost-effective boreholes in sub-Sa haran Africa.Water, Sanitation and Hygiene: Sustainable Development and Multisectoral Approaches.34th WEDC International Conference, Addis Ababa, Ethiopia, 2009

[16] Godfrey S. et al. (2019). Deep Groundwater as an Alternative Source of Water in the Ogaden Jesoma Sandstone Aquifers of Somali Region, Ethiopia.

[17] Drilling for Water in Ethiopia: A Country Case-Study by the Cost-Effective Boreholes Flagship of the Rural Water Supply Network. Final Report, Volume 1\&2 - Main Report, June 2006.Federal Democratic Republic of Ethiopia, Ministry of water Resources.

[18] Federal Democratic Republic of Ethiopia. One Wash National Program a Multi-Sectoral Swap Phase 2 Program Document Third Draft September 2018.

[19] Srinivas Chokkakula \& Mark Giordano (2013) Do policy and institutional factors explain the low levels of smallholder groundwater use in Sub-Saharan Africa? 
International Journal of Engineering Applied Sciences and Technology, 2021

Vol. 5, Issue 12, ISSN No. 2455-2143, Pages 176-181

Published Online April 2021 in IJEAST (http://www.ijeast.com)

Water International,38:6, 790-808, DOI:

$10.1080 / 02508060.2013 .843842$

[20] Water Works Design and Supervision Enterprise, 2008 Well Drilling Report.

[21] Hutton G, Haller L. Evaluation of the costs and benefits of water and sanitation improvements at the global level. Geneva: WHO; 2004. 